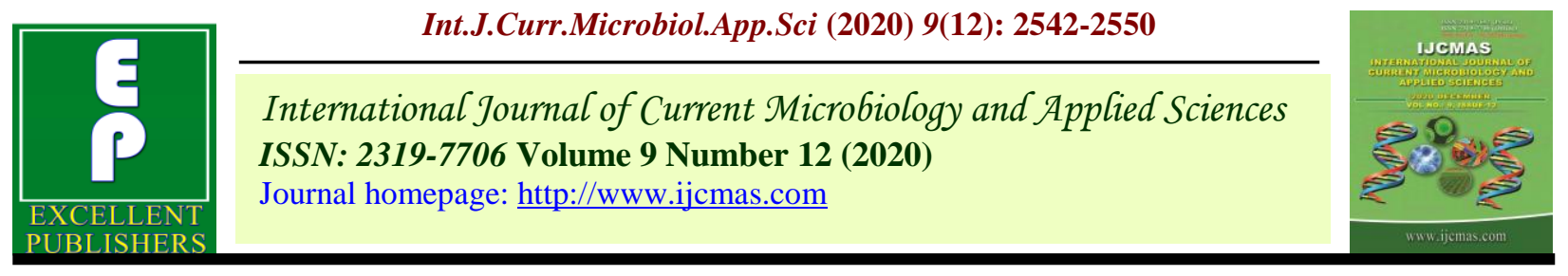

Original Research Article

https://doi.org/10.20546/ijcmas.2020.912.302

\title{
Effect of Crop Establishment Methods and Brown Manuring of Finger Millet (Eleusine coracana L. Gaertn) under Irrigated Ecosystem
}

\author{
Tamaskar Navrang, A. Pradhan*, M. Kumar, G. K. Sharma and D. P. Singh
}

S. G. College of Agriculture \& Research Station, IGKV, Jagdalpur (C.G.) 494005, India

*Corresponding author

\begin{tabular}{l} 
K e y w o r d s \\
$\begin{array}{l}\text { Finger millet, Crop } \\
\text { establishment } \\
\text { methods and brown } \\
\text { manuring, Summer, } \\
\text { Grain and straw }\end{array}$ \\
\hline Article Info \\
$\begin{array}{l}\text { Accepted: } \\
18 \text { November } 2020 \\
\text { Available Online: } \\
\text { 10 December } 2020\end{array}$ \\
\hline
\end{tabular}

\author{
A B S T R A C T
}

A field experiment was conducted on "Effect of crop establishment methods and brown manuring of finger millet (Eleusine coracana L. Gaertn) under irrigated ecosystem" at Instructional cum research farm, S.G. College of Agriculture and Research Station, Jagdalpur, Chhattisgarh, India during summer 2019 in Randomized Complete Block Design (RCBD) with seven treatments and three replications. Line sowing of Finger millet +DAP (30kg/ha.) of GPU-28 was carried out on $21^{\text {th }}$ January 2019 maintaining crop geometry of $30 \times 10 \mathrm{~cm}$ within each plot and finger millet was harvested on $28^{\text {st }}$ May 2019. The result showed that maximum plant height, tillers number per meter square, number of leaves per plant, leaf area index, relative growth rate N, P and K nutrient uptake in grain and straw, number of fingers per panicle, finger length, number of grains per fingerlet and weight of 1000 seeds were obtained with line sowing of finger millet $+\mathrm{DAP}$ (30kg/ha.).Throughout the observations which was found significant and comparable to line sowing of finger millet and dhaincha together (3:1) desiccated by 2, 4-D @ 1.0kg ha-1 at 30 DAS. The highest grain $\left(29.64 \mathrm{q} \mathrm{ha}^{-1}\right)$ and straw yield $\left(51.25 \mathrm{q} \mathrm{ha}^{-1}\right)$ of finger millet were noticed in line sowing of finger millet +DAP $(30 \mathrm{~kg} / \mathrm{ha}$.) .Which was significantly more than rest of the treatments except the line sowing of finger millet and broadcasting dhaincha (3:1) desiccated by 2, 4-D @ 1.0 $\mathrm{kg} \mathrm{ha}^{-1}$ at 30DAS. The lowest grain and straw yield (12.17 and $28.57 \mathrm{q} \mathrm{ha}^{-1}$ ) was recorded by broadcasting of finger millet (Check).

\section{Introduction}

Finger millet (Eleusine coracana (L.) Gaertn) is a crop of small millets belonging to the family Poaceae and the genus Eleusine. The common name "finger millet" is derived from the shape of the inflorescences which consists of a number of spikelets and resembles the shape of human fingers (Duke, 1983). Finger millet also known as Mandua, valued as staple food and first important crop among small millets. It contains $9.2 \%$ protein, $1.29 \%$ fat, $76.32 \%$ carbohydrate, $2.24 \%$ minerals and $3.9 \%$ ash besides vitamin A and B. The grains are rich in phosphorus, potassium and amino acid. It is for growing children and aged people (Tomar et al., 2011). In India finger millet (ragi) is cultivated over an area of 1.61 million hectares with total production of about 2.1 million tones and productivity 1661 $\mathrm{kg}$ per hectare (Anonymous, 2016). The finger millet alone occupied $6.9 \mathrm{~m}$ ha areas 
with the production of $1.3 \mathrm{~m}$.tons and productivity of $188 \mathrm{~kg} / \mathrm{ha}$ Chhattisgarh region (Anonymous, 2016). Several crop establishment methods are being adopted under finger millet cultivation but issue related to soil health and production potential are very crucial because finger millet is grown on rainfed upland where nutrients are always deficit. The optimum quantity of fertilizer is almost negligible in this types of lands. Priority to apply of fertilizers has been given to rice crop and least priority to finger millet in addition to applying fertilizer, the labour cost and soil health selected issues are burning problem.

The incorporation of dhaincha through drilling may be an optional measure to nourish the finger millet because finger millet needs less quantity of nutrients as compared to rice. Application of post-emergence herbicide on the green manure leaves resulting in loss of chlorophyll in leaves showing brown in colour is referred to as brown manuring (Tanwar et al., 2010). Green manure is the ideal source of organic matter, which influences on the crop production quality and soil fertility (Hemalatha et al., 2000). The drilling requires machines and less labours in sowing process make possible to cover more area in limited window of sowing during kharif season if adopted as direct seeding of finger millet on marginal lands. The poor growth after 20-25 days after sowing due to creation of hunger zones in the upland soil demands to add nutrients which can be fulfilled by incorporation of green manure and it may reduce fertilizer dose with sustainable availability than inorganic fertilizers. Green manuring requires adding in or ex-situ production with more labour and farmers do not accept such complicated process in cultivation of finger millet. So, drilling of dhaincha seed with finger millet in certain proportion and after 30 days of sowing selective herbicide might be used to kill the dhaincha in in-situ. Keeping that view in mind present investigation was conducted to offset the objectives of suitable nourishment methods and crop establishment with higher yields.

\section{Materials and Methods}

A field experiment was carried out at the Inceptisol of Instructional cum Research Farm, S.G. College of Agriculture and Research Station, Kumhrawand, Jagdalpur, Chhattisgarh, India during summer season 2019. Bastar lies at $19^{0} 10^{\prime} \mathrm{N}$ latitude and $81^{\circ} 95^{\prime}$ E longitude with an altitude of 552 meters above mean sea level. The average annual rainfall and temperature of the area is about $1451 \mathrm{~mm}$ and $31.6^{\circ} \mathrm{C}$, respectively were recorded via meteorological observatory of S.G. CARS, IGKV, Jagdalpur. The crop received $137.50 \mathrm{~mm}$ rainfall throughout its growth period and maximum temperature $\left(39.1^{\circ} \mathrm{C}\right)$ in second week of May and minimum temperature $\left(8.2^{\circ} \mathrm{C}\right)$ in second week of February along with maximum Sunshine was 9.3 hours in fourth week of April. The experiment was framed out in RCBD with three replications on Inceptisol.

The treatments comprised of $\mathrm{T}_{1}$ : line sowing of finger millet, $\mathrm{T}_{2}$ : broadcasting of finger millet with dhaincha $(3: 1)$ desiccated by $2,4-$ D @ $1.0 \mathrm{~kg} / \mathrm{ha}$ at $30 \mathrm{DAS}, \mathrm{T}_{3}$ : line sowing of finger millet and broadcasting dhaincha $(3: 1)$ desiccated by 2,4-D @ $1.0 \mathrm{~kg} / \mathrm{ha}$ at 30 DAS, $\mathrm{T}_{4}$ : line sowing of finger millet and dhaincha together (3:1) desiccated by 2,4-D @ 1.0kg /ha at $30 \mathrm{DAS}, \mathrm{T}_{5}$ : line sowing of finger millet +DAP (30kg/ha.) $\mathrm{T}_{6}$ : broadcasting of finger millet +DAP (30kg/ha.) $\mathrm{T}_{7}$ : broadcasting of finger millet (Check). The cultivar tested for the experiment was GPU-28, which is cross between (Krishna) Indaf-5 x IE-1012 is GPU28. It has medium duration variety (110-115 days) having characteristics features of resistant to neck blast and finger blast with 
the yield about 40-45q/ha and 30-35q/ha in irrigated and rainfed, respectively. As per the treatment, experimental plots were prepared and line sowing at the spacing of $30 \mathrm{~cm}$ and about $10 \mathrm{~cm}$ plant to plant distance were done on $21^{\text {th }}$ January 2019. A fertilizer dose of 50:30:20 N: P: K Kg ha ${ }^{-1}$ was applied to the finger millet field, at the time of field preparation all the fertilizers and half dose of the nitrogen was top dressed at 30 DAS. A green manure crop dhaincha (Sesbania aculeata Pers.) was sown along finger millet in summer. The dhaincha was smothered 30 days after of sowing by spraying 2,4-D @ 1.0 $\mathrm{kg} / \mathrm{ha}$. A pesticide chlorpyriphos was sprayed @ $2 \mathrm{ml} / \mathrm{l}$ to control the stem borer twice at 15 days and 45 days after sowing. The finger millet crop was harvested on $28^{\text {st }}$ May of 2019 after completion of the physiological maturity of the crop. All the observations recorded of pre and post-harvest on different intervals with respect to various growths, yield and laboratory studies were subjected to statistical analysis as per the guidelines of Gomez and Gomez (1984). The variance ratio (F-value) was used to test the significance of the treatment effect.

\section{Results and Discussion}

\section{Growth parameters}

The higher plant height $(112.95 \mathrm{~cm})$, number of tillers $\left(\mathrm{m}^{-2}\right)$ (99.18), number of leaves per plant (37.93), number of tillers were significant over rest of treatments except line sowing of finger millet and dhaincha together (3:1) desiccated by $2,4-\mathrm{D} @ 1.0 \mathrm{~kg} / \mathrm{ha}$ at 30 DAS, which was comparable to that of line sowing of finger millet + DAP (30kg/ha.). The lowest growth parameters were recorded under broadcasting of finger millet (Table 1). Regardless stage of observation, crop growth due to establishment of plants took more time with faster growth. This result confirms with the findings of Pradhan et al., (2018). The result obtained was similar with the works of Kalaraju et al., (2009). The highest LAI was obtained from line sowing of finger millet + DAP (30kg/ha.) (3.01) at 90 DAS being at par with line sowing of finger millet and dhaincha together (3:1) desiccated by 2, 4-D @ $1.0 \mathrm{~kg} / \mathrm{ha}$ at $30 \mathrm{DAS}$ (2.37) at 90 DAS. Similar outcomes were accompanied with research work of Baloch et al., (2006) and Kumara et al., (2007). The maximum (0.020 plant- ${ }^{1}$ day- ${ }^{1}$ during $30-60$ DAS crop growth rate was recorded with line sowing of finger millet + DAP $(30 \mathrm{~kg} / \mathrm{ha})$, the treatment line sowing of finger millet + DAP $(30 \mathrm{~kg} / \mathrm{ha})$ was significantly superior to other treatments at 0 30 DAS. Broadcasting of finger millet with dhaincha (3:1), line sowing of finger millet and broadcasting dhaincha (3:1) and line sowing of finger millet and dhaincha together (3:1), all were desiccated by 2,4-D @ 1.0 $\mathrm{kg} / \mathrm{ha}$ at 30 DAS were found at par with each other at 0-30 DAS. The increased trend was observed with first 60 days due to fast growth rate of biomass, later growth of the finger millet declined as reported by Prakasha et al., (2018). The higher plant height, leaf area index with more number of tillers directly contributed to the growth parameters of finger millet resulting in higher RGR.

\section{Yield attributes}

The significantly higheer number of finger panicle $^{-1}(7.46)$, finger length $(9.66 \mathrm{~cm})$ and grains per fingerlets (1175) were obtained through line sowing of finger millet + DAP $(30 \mathrm{~kg} / \mathrm{ha})$ followed by line sowing of finger millet and dhaincha together (3:1) desiccated by 2,4-D @ $1.0 \mathrm{~kg} / \mathrm{ha}$ at 30 DAS and line sowing of finger millet and broadcasting of dhaincha (3:1) desiccated by 2,4-D @ 1.0 $\mathrm{kg} / \mathrm{ha}$ at 30 DAS being at par with each other. Memon et al., (2013) observed that the highest number of fingers earhead ${ }^{-1}$ under spaced crop (Table 1). As the finger length increased the panicle length, which may be a 
reason for increasing in yield attributes as mentioned by Prabakaran et al., (1995). The increase in grains per fingerlets basically depends on finger length (Kumar et al., 2020).

\section{Yields of finger millet}

The results on yields of finger millet included grain yield, straw yield and harvest index (HI). The seed yield was influenced significantly with the different methods of dhaincha incorporation. The maximum average seed yield was recorded with line sowing of finger millet +DAP $(30 \mathrm{~kg} / \mathrm{ha})$ (29.64 $\left.\mathrm{q} \mathrm{ha}^{-1}\right)$ which was statistically at par with line sowing of finger millet and dhaincha together (3:1) desiccated by 2, 4-D (a) $1.0 \mathrm{~kg} / \mathrm{ha}$ at $30 \mathrm{DAS}\left(26.11 \mathrm{q} \mathrm{ha}^{-1}\right)$. The yield attributing characters provided better opportunity for higher grain yield of finger millet (Table 2).

The minimum grain yield was recorded when broadcasting of finger millet $\left(12.17 \mathrm{q} \mathrm{ha}^{-1}\right)$, which was improved by applying line sowing and incorporation of dhaincha, as reflected higher grain yield with line sowing of finger millet and broadcasting dhaincha (3:1) desiccated by 2, 4-D @ $1.0 \mathrm{~kg} / \mathrm{ha}$ at 30DAS (22.35 $\mathrm{q} \mathrm{ha}^{-1}$ ) being at par with line sowing alone and dhaincha incorporation.

These findings were similar to the finding of Prabakaran et al., (1995) who recorded significantly higher grain yield and straw yield. Similar trends were followed by straw yield and harvest index, Mankotia et al., (2009) found the same trend with HI. The highest straw yield was obtained in line sowing of finger millet +DAP (30kg/ha.) which was about 51.25 and $45.09 \mathrm{q} \mathrm{ha}^{-1}$ higher over line sowing and broadcasting alone. The lowest straw yield was recorded with broadcasting method of finger millet which was 28.57qha ${ }^{-1}$ (Raj et al., 2013).

\section{$\mathbf{N}, \mathbf{P}$ and $\mathbf{K}$ uptake in grain and straw of finger millet}

\section{N uptake $\left(\mathrm{kg} \mathrm{ha}^{-1}\right)$}

The data pertaining to $\mathrm{N}$ uptake in grain and straw were depicted in Table 3. The highest $\mathrm{N}$ uptake in grain $\left(32.70 \mathrm{~kg} \mathrm{ha}^{-1}\right)$ and straw (29.32 $\mathrm{kg} \mathrm{ha}^{-1}$ ) were recorded under line sowing of finger millet +DAP $(30 \mathrm{~kg} / \mathrm{ha})$ followed by line sowing of normal seeds (32.20 and $28.65 \mathrm{~kg} \mathrm{ha}^{-1}$ in grain and straw, respectively), which was comparable to line sowing of finger millet +DAP $(30 \mathrm{~kg} / \mathrm{ha})$. Broadcasting of finger millet with dhaincha (3:1) desiccated by 2,4-D @ 1.0kg/ha at 30 DAS and Line sowing of Finger millet and dhaincha together (3:1) desiccated by $2,4-\mathrm{D}$ @ $1.0 \mathrm{~kg} / \mathrm{ha}$ at $30 \mathrm{DAS}$ were found similar in uptake of nitrogen in case of grain and straw. The lowest nitrogen uptake by grain and straw was noted in broadcasting of finger millet (Check). The higher biomass accumulation is directly reflected in uptake of $\mathrm{N}$ (Nanjappa et al., 1987).

\section{P uptake (kg ha $\left.{ }^{-1}\right)$}

The data on $\mathrm{P}$ uptake in grain and straw were recorded and depicted in Table 3 . The highest $\mathrm{P}$ uptake in grain $\left(8.09 \mathrm{~kg} \mathrm{ha}^{-1}\right)$ and straw $\left(11.01 \mathrm{~kg} \mathrm{ha}^{-1}\right)$ were recorded under line sowing of finger millet +DAP $(30 \mathrm{~kg} / \mathrm{ha})$ then line sowing of finger millet and broadcasting dhaincha (3:1) desiccated by 2,4-D @ 1.0 $\mathrm{kg} / \mathrm{ha}$ at $30 \mathrm{DAS}$, both were found on par to each other, being similar to line sowing of finger millet + DAP $(30 \mathrm{~kg} / \mathrm{ha})$. Broadcasting of finger millet with dhaincha (3:1) desiccated by 2,4-D@1.0kg/ha at 30 DAS and line sowing of finger millet and dhaincha together (3:1) desiccated by 2,4-D @ 1.0 $\mathrm{kg} / \mathrm{ha}$ at $30 \mathrm{DAS}$ were found similar in uptake of phosphorus in grain and straw of finger millet. The lowest phosphorus uptake by grain and straw was noted in broadcasting of finger millet (Check). 
Table.1 Effect of crop establishment methods on plant growth of summer finger millet

\begin{tabular}{|c|c|c|c|c|c|c|c|c|}
\hline Treatment & $\begin{array}{l}\text { Plant } \\
\text { height }(\mathrm{cm}) \\
\text { at harvest }\end{array}$ & $\begin{array}{l}\text { No. of } \\
\text { tillers } \\
\left(\mathbf{M}^{-2}\right) \text { at } \\
\text { harvest }\end{array}$ & $\begin{array}{l}\text { No. of } \\
\text { leaves at } \\
\text { harvest }\end{array}$ & $\begin{array}{l}\text { LAI }(90 \\
\text { DAS) }\end{array}$ & $\begin{array}{l}30-60 \\
\text { DAS }\end{array}$ & $\begin{array}{l}\text { No. of } \\
\text { fingers/ } \\
\text { panicle }\end{array}$ & $\begin{array}{l}\text { Finger } \\
\text { length } \\
(\mathrm{Cm})\end{array}$ & $\begin{array}{l}\text { No. of } \\
\text { grains/ } \\
\text { Fingerlet } \\
\text { S }\end{array}$ \\
\hline$T_{1}$ :Line sowing of finger millet & 97.81 & 84.88 & 25.73 & 1.88 & 0.015 & 6.13 & 9.03 & 1036 \\
\hline $\begin{array}{l}T_{2} \text { :Broadcasting of finger millet with dhaincha } \\
\text { (3:1) desiccated by 2,4-D@1.0 kg } \\
\text { ha }^{-1} \text { at } 30 \text { DAS }\end{array}$ & 98.83 & 86.65 & 26.10 & 1.91 & 0.016 & 6.20 & 8.50 & 1077 \\
\hline $\begin{array}{l}T_{3}: \text { Line sowing of finger millet and } \\
\text { broadcasting dhaincha }(3: 1) \text { desiccated by } \\
2,4-D @ 1.0 \mathrm{~kg} \mathrm{ha}^{-1} \text { at } 30 \mathrm{DAS}\end{array}$ & 101.96 & 87.57 & 30.60 & 2.33 & 0.018 & 6.46 & 9.50 & 1093 \\
\hline $\begin{array}{l}\mathrm{T}_{4} \text { : Line sowing of finger millet and dhaincha } \\
\text { together (3:1) desiccated by 2, 4-D @ } 1.0 \mathrm{~kg} \\
\text { ha }^{-1} \text { at } 30 \text { DAS }\end{array}$ & 110.10 & 90.03 & 35.26 & 2.37 & 0.019 & 6.60 & 9.27 & 1129 \\
\hline $\begin{array}{c}T_{5}: \text { Line sowing of finger millet }+ \text { DAP } \\
(30 \mathrm{~kg} / \mathrm{ha} .)\end{array}$ & 112.95 & 99.18 & 37.93 & 3.01 & 0.020 & 7.46 & 9.66 & 1175 \\
\hline $\begin{array}{c}\text { T}_{6}: \text { Broadcasting of finger millet }+ \text { DAP } \\
(30 \mathrm{~kg} / \mathrm{ha} .)\end{array}$ & 95.81 & 84.01 & 22.63 & 1.42 & 0.014 & 5.4 & 9.36 & 1076 \\
\hline $\mathbf{T}_{7}:$ Broadcasting of finger millet (Check) & 91.48 & 81.04 & 20.53 & 1.32 & 0.012 & 5.26 & 9.23 & 931 \\
\hline SEm \pm & 3.53 & 3.26 & 2.74 & 0.21 & $\mathbf{0 . 0 0 3}$ & 0.44 & 0.16 & 16.52 \\
\hline $\mathrm{CD}(\mathrm{P}=\mathbf{0 . 0 5})$ & 11.01 & 9.75 & 8.55 & 0.63 & NS & 1.12 & 0.56 & 56.23 \\
\hline
\end{tabular}


Table.2 Effect of crop establishment methods on yield of finger millet

\begin{tabular}{|c|c|c|c|c|c|}
\hline Treatments & $\begin{array}{c}\text { Grain } \\
\text { yield } \\
\left(\text { qha }^{-1}\right)\end{array}$ & $\begin{array}{c}\text { Straw } \\
\text { yield } \\
\left(\mathbf{q ~ h a}^{-1}\right)\end{array}$ & $\begin{array}{c}\text { Harves } \\
\text { t Index } \\
(\%)\end{array}$ & $\begin{array}{l}\text { Net } \\
\text { return } \\
(\text { Rs. ha-1) }\end{array}$ & $\begin{array}{l}\text { B:C } \\
\text { ratio }\end{array}$ \\
\hline $\mathrm{T}_{1}:$ Line sowing of finger millet & 14.08 & 41.56 & 28.85 & 16,851 & 1.96 \\
\hline $\begin{array}{l}\mathrm{T}_{2}: \text { Broadcasting of finger millet with dhaincha }(3: 1) \\
\text { desiccated by 2,4-D @ } 1.0 \mathrm{~kg} \mathrm{ha}^{-1} \text { at } 30 \mathrm{DAS}\end{array}$ & 17.25 & 38.25 & 35.43 & 22,146 & 2.22 \\
\hline $\begin{array}{l}\mathrm{T}_{3} \text { : } \text { Line sowing of finger millet and broadcasting } \\
\text { dhaincha }(3: 1) \text { desiccated by } 2,4-\mathrm{D} \text { @ } 1.0 \mathrm{~kg} \mathrm{ha}^{-1} \\
\text { at } 30 \text { DAS }\end{array}$ & 22.35 & 41.25 & 40.06 & 29,569 & 2.35 \\
\hline $\begin{array}{l}\mathrm{T}_{4}: \text { Line sowing of finger millet and dhaincha } \\
\text { together }(3: 1) \text { desiccated by } 2,4-\mathrm{D} @ 1.0 \mathrm{~kg} \mathrm{ha}^{-1} \\
\text { at } 30 \text { DAS }\end{array}$ & 26.11 & 45.09 & 40.78 & 34,928 & 2.63 \\
\hline$T_{5}:$ Line sowing of finger millet + DAP (30kg/ha.) & 29.64 & 51.25 & 41.77 & 43,467 & 2.85 \\
\hline$T_{6}:$ Broadcasting of finger millet + DAP $(30 \mathrm{~kg} / \mathrm{ha})$. & 16.93 & 33.25 & 38.46 & 21,148 & 2.19 \\
\hline $\mathbf{T}_{7}:$ Broadcasting of finger millet (Check) & 12.17 & 28.57 & 34.05 & 11,868 & 1.71 \\
\hline SEn & 1.61 & 3.19 & 0.58 & 4666 & 0.08 \\
\hline $\mathrm{CD}(\mathrm{P}=0.05)$ & 4.81 & 9.53 & 1.73 & 13,905 & 0.24 \\
\hline
\end{tabular}

Table. 3 Effect of crop establishment methods on nutrient uptake $\left(\mathrm{kg} \mathrm{ha}^{-1}\right)$ by grain and straw

\begin{tabular}{|c|c|c|c|c|c|c|}
\hline \multirow[t]{3}{*}{ Treatment } & \multicolumn{6}{|c|}{ Nutrient uptake $\left(\mathrm{kg} \mathrm{ha}^{-1}\right)$ at harvest } \\
\hline & \multicolumn{2}{|c|}{ N uptake } & \multicolumn{2}{|c|}{ P uptake } & \multicolumn{2}{|c|}{ K uptake } \\
\hline & Grain & Straw & Grain & Straw & Grain & Straw \\
\hline$T_{1}$ :Line sowing of finger millet & 29.24 & 23.19 & 7.07 & 8.88 & 9.93 & 25.07 \\
\hline $\begin{array}{l}\mathrm{T}_{2}: \text { Broadcasting of finger millet with } \\
\text { dhaincha }(3: 1) \text { desiccated by } 2,4 \mathrm{D} \text { @ } \\
1.0 \mathrm{~kg} / \text { ha at } 30 \mathrm{DAS}\end{array}$ & 31.90 & 27.63 & 7.25 & 6.07 & 10.42 & 27.40 \\
\hline $\begin{array}{l}\mathrm{T}_{3}: \text { Line sowing of finger millet and } \\
\text { broadcasting dhaincha }(3: 1) \text { desiccated } \\
\text { by } 2,4-\mathrm{D} @ 1.0 \mathrm{~kg} / \mathrm{ha} \text { at } 30 \mathrm{DAS}\end{array}$ & 32.20 & 28.65 & 7.70 & 10.38 & 10.53 & 30.01 \\
\hline $\begin{array}{l}\mathrm{T}_{4}: \text { Line sowing of finger millet and } \\
\text { dhaincha together (3:1) desiccated by } 2 \text {, } \\
\text { 4-D @ } 1.0 \mathrm{~kg} / \mathrm{ha} \text { at } 30 \mathrm{DAS}\end{array}$ & 31.22 & 29.57 & 6.98 & 9.91 & 10.42 & 28.21 \\
\hline $\begin{array}{l}\mathrm{T}_{5}: \text { Line sowing of finger millet }+ \text { DAP } \\
(30 \mathrm{~kg} / \mathrm{ha} .)\end{array}$ & 32.70 & 29.32 & 8.09 & 11.01 & 10.98 & 31.58 \\
\hline $\begin{array}{l}\mathrm{T}_{6}: \text { Broadcasting of finger millet +DAP } \\
\text { (30kg/ha.) }\end{array}$ & 28.38 & 22.19 & 6.79 & 8.95 & 8.85 & 24.26 \\
\hline $\mathrm{T}_{7}:$ Broadcasting of finger millet (Check) & 26.65 & 29.60 & 6.10 & 6.07 & 7.54 & 20.72 \\
\hline & & 0.23 & 0.13 & 0.22 & 0.16 & 0.55 \\
\hline $\mathrm{CD}(\mathrm{P}=\mathbf{0 . 0 5})$ & 0.52 & 0.66 & 0.38 & 0.64 & 0.47 & 1.58 \\
\hline
\end{tabular}


Table.4 Effect of crop establishment methods on Economics of finger millet

\begin{tabular}{|c|c|c|c|}
\hline Treatments & $\begin{array}{l}\text { Cost of cultivation } \\
\left(\text { Rs. ha- }{ }^{1}\right)\end{array}$ & $\begin{array}{l}\text { Gross Return } \\
\left(\text { (Rs.ha- }{ }^{1}\right)\end{array}$ & B:C \\
\hline$T_{1}:$ Line sowing of finger millet & 17,543 & 34,394 & 1.96 \\
\hline $\begin{array}{l}\mathrm{T}_{2}: \text { Broadcasting of finger millet with } \\
\text { dhaincha }(3: 1) \quad \text { desiccated by } \\
\text { 2,4-D @ } 1.0 \mathrm{~kg} \mathrm{ha}^{-1} \text { at 30DAS }\end{array}$ & 18,092 & 40,238 & 2.22 \\
\hline $\begin{array}{l}\mathrm{T}_{3}: \text { Line sowing of finger millet and } \\
\text { broadcasting dhaincha }(3: 1) \text { desiccated } \\
\text { by 2,4-D @ } 1.0 \mathrm{~kg} \mathrm{ha}^{-1} \text { at 30DAS }\end{array}$ & 21,895 & 51,464 & 2.35 \\
\hline $\begin{array}{l}T_{4}: \text { Line sowing of finger millet and } \\
\text { dhaincha together (3:1) desiccated by } 2 \text {, } \\
\text { 4-D @ } 1.0 \mathrm{~kg} \mathrm{ha}^{-1} \text { at } 30 \mathrm{DAS}\end{array}$ & 23,480 & 56,408 & 2.63 \\
\hline $\begin{array}{l}T_{5}: \text { Line sowing of finger millet + DAP } \\
(30 \mathrm{~kg} / \mathrm{ha} .)\end{array}$ & 23,500 & 66,958 & 2.85 \\
\hline $\begin{array}{l}T_{6}: \text { Broadcasting of finger millet + DAP } \\
(30 \mathrm{~kg} / \mathrm{ha} .)\end{array}$ & 17,700 & 38,848 & 2.19 \\
\hline $\mathbf{T}_{7}$ : Broadcasting of finger millet (Check) & 16,758 & 28,626 & 1.71 \\
\hline SEm \pm & 680 & 5204 & 0.08 \\
\hline $\mathrm{CD}(\mathrm{P}=\mathbf{0 . 0 5})$ & 2025 & 15,508 & 0.24 \\
\hline
\end{tabular}

K uptake (kg ha $\left.{ }^{-1}\right)$

The data showed on $\mathrm{K}$ uptake in grain and straw were recorded and depicted in Table 3. The highest $\mathrm{K}$ uptake in grain $\left(10.98 \mathrm{~kg} \mathrm{ha}^{-1}\right)$ and straw $\left(31.58 \mathrm{~kg} \mathrm{ha}^{-1}\right)$ under line sowing of finger millet +DAP $(30 \mathrm{~kg} / \mathrm{ha})$ being at par with broadcasting dhaincha (3:1) desiccated by 2,4-D @ $1.0 \mathrm{~kg} / \mathrm{ha}$ at 30 DAS (10.53 and $30.01 \mathrm{~kg} / \mathrm{ha}$ in grain and straw, respectively). Whereas, dhaincha incorporation through broadcasting and drilling in finger millet gave similar uptake of potash which were identical in uptake at harvest and the treatments $\left(T_{2}, T_{3}\right.$ and $\mathrm{T}_{4}$ ) were found on par to each other. The lowest potash uptake by grain and straw was noted in broadcasting of finger millet (Check).

\section{Economics}

Economical analysis of trial was done on the basis of prevailing market price of finger millet consisted of cost of cultivation, gross return, net return and $\mathrm{B}: \mathrm{C}$ ratio are depicted in Table 4. The maximum cost of cultivation (23500 ₹ $\mathrm{ha}^{-1}$ ) was recorded with line sowing of finger millet +DAP (30kg/ha.) being significantly superior over rest of treatments except line sowing of finger millet and dhaincha together (3:1) desiccated by 2, 4-D @ $1.0 \mathrm{~kg} / \mathrm{ha}$ at $30 \mathrm{DAS}\left(23,480 ₹ \mathrm{ha}^{-1}\right)$ which was at par to that of line sowing of finger millet +DAP (30kg/ha). The difference in cost of cultivation was not much because of both the methods had similar operations and sowing performed by mixing dhaincha whereas DAP applied with seed cum fertilizer drill that is why no extra cost involved. The incorporation of dhaincha has elicited by higher cost of cultivation as compared to other methods of sowing due to high input cost in broadcasting of dhaincha, which reflected to be higher cost of cultivation. Al though, the high labour input mitigated with more yields which also benefited in the line of 
compensation. Whereas, the minimum cost of cultivation was obtained under broadcasting method of sowing $\left(16,758\right.$ ₹ $\left.\mathrm{ha}^{-1}\right)$. The finding is greater conformity with the result of Ahiwale et al., (2013), reported that line sowing of finger millet gave the highest gross returns, net returns and benefit to cost ratio. Income improved with imposing treatments through either line sowing or green manuring of dhaincha procured 17,543 and 18,092 ₹ $\mathrm{ha}^{-1}$ in case of line sowing of finger millet and broadcasting of finger millet with dhaincha (3:1) desiccated by 2,4-D @ 1.0kg/ha at 30 DAS, respectively. Further, it was more pronounced when line sowing of finger millet and broadcasting dhaincha (3:1) desiccated by 2, 4-D @ $1.0 \mathrm{~kg} / \mathrm{ha}$ at 30DAS was done $\left(21,895 ₹ \mathrm{ha}^{-1}\right)$ in increasing cost of cultivation, and ultimately yields increased under the particular treatments. Similar trend was observed in gross and net returns having maximum 66,958 and 43,467 ₹ $\mathrm{ha}^{-1}$ under line sowing of finger millet + DAP $(30 \mathrm{~kg} / \mathrm{ha})$. The lowest cost of cultivation, gross return and net return was with broadcasting of finger millet $\left(\mathrm{T}_{7}\right)(16,758,28,626$ and 11,868).

The highest B: C ratio was recorded when finger millet crop was grown by line sowing of finger millet +DAP (30kg/ha) (2.85) than rest of treatments except line sowing of finger millet and dhaincha together (3:1) desiccated by $2,4-\mathrm{D} @ 1.0 \mathrm{~kg} / \mathrm{ha}$ at $30 \mathrm{DAS}(2.63)$. In contract the lowest was with broadcasting of finger millet (1.71). The more $\mathrm{B}$ : $\mathrm{C}$ ratio was contributed by yield and yield component directly ultimately led to the incomes of the treatments. Similar trend was observed by Roy et al., (2001).

\section{References}

Aranachalam, A. A., Veerabadran, V. and Muthushankara, A. 1995. Integrated nitrogen supply system for finger millet Indian J. Agron. 40: 109-11.

Ahiwale, P. H., Chavan, L. S. and Jagtap, D. N.
2011. Effect of crop establishment methods and nutrient management on yield attributes and yields of finger millet (Eleusine coracana G.). Adv. res. j. crop impr. 2(2): 247-250.

Ahiwale, P. H., Chavan, L.S., Jagtap, D. N., Mahadkar, U. V. and Gawade M .B. 2013. Effect of establishment methods and nutrient management on yield attributes and yields of finger millet (Eleusine coracana G.). Crop Res. 45(13):141-145.

Awan, T.H., Ali, I., Safdar, M.E., Ashraf, M.M. and Yaqub, M. 2007. Economic effect of different plant establishment techniques on rice, Oryza sativa production. Journal of Agricultural Research, 45(1): 73-81.

Anonymous. 2016. ICAR-All India Coordinated Research Project on Small Millets ICAR, (AICSMIP). GKVK Campus, Bangalore. Official site http://www.aicrpsm.res.in

Baloch, M.S., Awan, I.U., Hassan, G. and Khakwani, A.A. 2006. Effect of establishment methods and weed management practices on some growth attributes of rice. Rice Science, 13(2): 131-140.

Duke, J.A.1983. Eleusine coracana L. Gaerth Handbook of energycrops. Unpublished. Purdue University. Center for new crop and plant products West Lafayette Indiana.

Gomez, K.A. and Gomez, A.A. 1984. Statistical procedures for Agricultural Research. A Willey.

Heering, J.H. 1995. Botanical and agronomic evaluation of a collection of Sesbania sesban and related perennial species. Doctoral Thesis, Wageningen Agril. Univ. Wageningen. The Netherlands.

Hemalatha, M., Thirumurugan, V. and Balasubramanian, R. 2000. Effect of organic sources of nitrogen on productivity, quality of rice (Oryza sativa) and soil fertility in single crop in wetlands. Indian J. Agron. 45(3):564-567.

Kalaraju, K., Kumar, N. S., Nagaraja, N. and Ningappa, K. B. 2009. Effect of methods of planting on growth and yield of finger 
millet genotypes under organic farming. Res. Crops, 10: 20- 24.

Kumara, O., Naik, T. B. and Kumar A. B. M. 2007. Effect weeds management practices and fertility levels on soil health in finger millet-groundnut cropping system. Inter. J. of Agric. Sci. 10 (1): 351-355

Kumar, N. S. and Paramasivan, M. 2020. Evaluate the establishment techniques on growth and yield of finger millet (Eleusine coracana) J. of Pharmacognosy and Phytochemistry 6: 153- 155

Mankotia, B.S., Shekhar, J. and Negi, S.C. 2009. Effect of crop establishment techniques on productivity of rice-wheat cropping system. Oryza, 46(3): 205-208.

Memon, S.Q., Mirjat, M.S., Mughal, A.Q. and Amjad, N. 2013. Effect on conventional and non- conventional tillage practices on maize production. Pakistan J. Agril. Engin. and Vet. Sci. 29 (2): 155-163

Nanjappa, H.V., Hosmani, M. M., and Chetty, T. K. P. 1987. Nutrient uptake by crop and weeds as influenced by crop weed competition under different cropping system in finger millet. Mysore J. Agri. Sci. 21(2): 140-144

Prabakaran, J., Udayasoorian, C. and Srinivasan, K. 1995. Significance of Azospirillum brassilense and Pseudomonas striata on growth and yield of ragi (Eleusine coracana) in alfisol. Text book of biofertilizers and biopesticides, (3):2126.

Pradhan, A., Nag, S. K. and Mukherjee, S. C.
2018. Thermal requirement of small millets in Chhattisgarh plateau under rainfed cropping situation. J. of Agrometeo. 20 (3):244-245.

Prakash, G., Kalyanamurthy, K. N., Prathima, A. N. and Meti, N. 2018. Effect of spacing on growth attributes and yield of finger millet (Eleusine coracana $\mathrm{L}$. Geartn ) cultivated under gani planting in red sandy loamy soil of Karnataka ,india. Int. j. of curr. Mic. And app. sci. ISSN: 2319 -7706 Vol.7. 1337- 134.

Rajesh, K. 2011. System of crop intensification in finger millet (Eleusine coracana L. Gareth.) Under irrigated condition. M. Sc. (Ag.) Thesis, TNAU, Coimbatore.

Roy, D. K., Chakrabarty, T., Sounda, G., and Maitra, S. 2001 Effect of fertility levels and plant populations on yield and uptake of nitrogen, phosphorus

Raj, S.K., Jose, N., Mathew, R. and S, L. 2013. Influence of stand establishment techniques on yield and economics of rice cultivation in Kuttanad. International Journal of Scientific and Research Publications, 3: 1-6.

Tanwar, S.P.S., Singh, A.K., and Joshi, N.2010. Changing environment and sustained crop production A challenge for agronomy. Journal of Arid Legumes. 7(2): 91-100.

Tomar, G.S., Taunk, S.K. and Choudhary, J.L. 2011. Science of crop production part-1 kharif crop. Kushal publication, Varanasi, India. Pp.182-183.

\section{How to cite this article:}

Tamaskar Navrang, A. Pradhan, M. Kumar, G. K. Sharma and Singh, D. P. 2020. Effect of Crop Establishment Methods and Brown Manuring of Finger Millet (Eleusine coracana L. Gaertn) under Irrigated Ecosystem. Int.J.Curr.Microbiol.App.Sci. 9(12): 2542-2550. doi: https://doi.org/10.20546/ijcmas.2020.912.302 